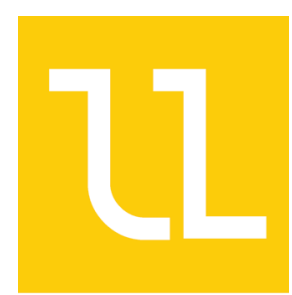

\title{
Hidraulikus kötóanyaggal stabilizált talajok teherbírásának értékelése ciklikus CBR-vizsgálattal
}

\author{
Primusz Péter ${ }^{1}, K_{i s f a l u d i}$ Balázs ${ }^{1}$, Péterfalvi József $^{1}$ \\ ${ }^{1}$ Soproni Egyetem, Erdőmérnöki Kar, Geomatikai, Erdőfeltárási és Vízgazdálkodási Intézet \\ e-mail:primusz.peter@uni-sopron.hu;kisfaludi@gmail.com; peterfalvi.jozsef@uni-sopron.hu
}

Kivonat Opiyo 1995 kidolgozta a ciklikus CBR-(cCBR) eljárásnak nevezett módszert annak érdekében, hogy a szemcsés útépítési anyagok reziliens modulusát $\left(M_{r}\right)$ a $C B R$-vizsgáló berendezéssel meg lehessen határozni. A jelen kutatásban a cCBR-eljárást mész-cement keverékkel stabilizált iszapos homokliszt talajokon teszteltük. A vizsgálathoz 18 db 3, 5 és 7\%, 70-30 arányú mész-cement keverék hozzáadásával próbatestet készítettünk 10-22\% tervezett kiindulási víztartalom mellett. A minták teherbírásának kifejezésére három mérószámot használtunk: 1. az általánosan használt CBR\% érték, 2. a cCBR-vizsgálat eredményeként meghatározott terhelöeró és rugalmas alakváltozás függvényében kiszámított $M_{r}$-érték, illetve 3. a CBR-értékból számított reziliens modulus. A kísérleti eredmények azt mutatták, hogy a kiindulási víztartalom nagyobb hatással volt a teherbírásra, mint a kötóanyag adagolás. A cCBR eljárást könnyen kivitelezhetönek találtuk. A vizsgálat eredményeit az Opiyo, illetve a Molenaar által kidolgozott képlet segítségével lehet átszámítani reziliens modulus értékre. Az Opiyoképlettel kapott $M_{r}$-értékek az irodalomban a hasonló talajokra megadott értékhatárokon belülre estek. A CBR-értékból számított reziliens modulus értékek igen nagy szórást mutattak. Webb és Campbell, valamint Uzan képlete a Molenaar-képlettel számított reziliens modulusokhoz hasonló eredményt adott.

Kulcsszavak ciklikus CBR, reziliens modulus, teherbírás, analitikus méretezés, talajstabilizáció

\section{Evaluating the bearing capacity of hydraulic road binder treated soils by the cyclic CBR method}

Abstract The cyclic CBR (cCBR) method was developed by Opiyo (1995) in order to determine the resilient modulus $\left(M_{r}\right)$ of unbound road construction materials with the standard CBR machine. In this research, the CCBR method was applied to lime-portland cement stabilized silty sand soils. 18 soil samples were produced with 70-30\% lime-cement binder, 10-22\% water content and 3\%, 5\% and 7\% binder dosage. The bearing capacity of the treated soils was expressed by three metrics: 1) the classic CBR\% value, 2) the resilient modulus calculated based on the force and elastic deformation resulted from the CCBR procedure and 3) the resilient modulus calculated from the $C B R \%$ value. It was found that the water content had greater effect on the bearing capacity than the binder dosage. The CCBR method proved to be an easy-to-use evaluation tool. The results of the test were transformed into resilient modulus value by the equations presented by Opiyo or by Molenaar. The calculated $M_{r}$ values by Opiyo corresponded well with the $M_{r}$ values derived from the literature. The resilient moduli values calculated from the CBR showed great variance. The results of the equations of Webb \& Campbell and Uzan corresponded well with the moduli calculated with the Molenaar equation.

Keywords cyclic CBR, resilient modulus, bearing capacity, analytical pavement design, soil stabilization

\section{Dr. Primusz Péter}

A Soproni Egyetem (SOE) Erdómérnöki Karán a Geomatikai, Erdőfeltárási és Vízgazdálkodási Intézet munkatársa. Fó kutatási területe az útfenntartás és az útpályaszerkezetek méretezése, megerősítése. 


\section{Dr. Kisfaludi Balázs}

2019 februárjáig a Soproni Egyetem (SOE) Erdómérnöki Karán a Geomatikai, Erdőfeltárási és Vízgazdálkodási Intézet munkatársa volt. Elsődlegesen erdészeti utak forgalomelemzésével foglalkozott, emellett részt vett talajstabilizációval, illetve úthálózatok vizsgálatával foglalkozó kutatásokban.

\section{Dr. habil Péterfalvi József}

Soproni Egyetem (SOE), Erdőmérnöki Kar, Geomatikai, Erdőfeltárási és Vízgazdálkodási Intézet, Erdőfeltárási Tanszék. Fő szakterület: erdőfeltárás, erdészeti útépítés. Oktatott tárgyak: Erdészeti utak tervezése és építése, Feltáróhálózatok tervezése, Erdészeti utak számítógépes tervezése, Infrastruktúra és közlekedés. Az Erdészeti utak tervezési irányelveinek egyik kidolgozója. Szakmai gyakorlati tevékenység: részvétel több mint 130 km erdészeti, 8,6 km kerékpárút tervének kidolgozásában, több mint 20 szakértés.

\section{Háttér}

A nem aszfaltburkolatú erdészeti feltáró utak komoly kihívás elé állítják az erdőgazdálkodót, hiszen ezeken az utakon a faanyag szállíthatóságát az idôjárás nagymértékben befolyásolja. Különösen igaz ez a klímaváltozás fényében, merthogy a fagyos napok száma csökken, aminek következtében a földutak a fakitermelési idôszakban szállításra alkalmatlan állapotban vannak. Egy földút hagyományos - makadám vagy aszfalt - burkolattal történő ellátása jelentốs anyagi ráfordítást igényel, ami nem minden esetben áll rendelkezésre. Ezért az erdőgazdálkodók folyamatosan keresik azokat a megoldásokat, amelyek segítségével jó ár-érték arányú pályaszerkezetek építhetốk, és amelyek jelentôsen megnyújtják a forgalmazható idôszakot. A pályaszerkezetek építési költségét jelentôsen csökkenteni lehet a helyi anyagok felhasználásával. A helyi talajok a fizikai féleségüknek megfelelố kötőanyag hozzáadásával jól megmunkálhatóvá, illetve teherbíróvá tehetốk. A közútépítési gyakorlatban a stabilizált helyi talaj teherbírását nem veszik figyelembe, ám az erdészeti útépítésben nagy biztonsággal a pályaszerkezet teherbíró részének tekinthetô.

A gazdaságos, alacsony költséggel építhetố pályaszerkezetek tervezésére és kivitelezésére különösen nagy figyelmet kell fordítani, hiszen a költségek csökkentését nem varázsszerekkel, hanem precízen meghatározott anyagmennyiségekkel és építési technológiával érik el. Az erdészeti utak közutakéhoz viszonyított alacsony építési költsége általában nem bírja el a magas tervezési költséget. A számítástechnika fejlődésével, illetve az egyre bốvülố anyagismerettel azonban a tervezốnek lehetôsége nyílik a klasszikus CBR módszer helyett az újszerú, precíz anyagparamétereket felhasználó analitikus, mechanikai alapú pályaszerkezet méretezési módszer használatára. Ez a méretezési eljárás a pályaszerkezetet egymásra helyezett rugalmas lemezekként képzeli el. A lemezrendszer terhelésre adott válaszát a lemezek rugalmasságát le- író anyagparaméterek, valamint a lemezek közti kapcsolat függvényében lehetséges kiszámítani. $\mathrm{Az}$ analitikus méretezéshez szükséges anyagparaméterek közvetlenül a dinamikus triaxiális vizsgálattal határozhatók meg, ám ez a vizsgálat összetett és drága felszerelést igényel (Araya et al., 2010). Az egyszerúbb vizsgálatok (CBR, Egyirányú nyomóvizsgálat) eredményeinek átszámítását több szerzó is megkísérelte, de az átszámított eredmények között nagy eltérések mutatkoztak. Opiyo (1995) kidolgozott egy olyan eljárást, amellyel az egyszerú CBR-vizsgáló berendezést felhasználva vizsgálható a talajminták rugalmas viselkedése. Az ciklikus CBR-eljárásnak nevezett módszer nagyban hozzájárulhat ahhoz, hogy a stabilizációs pályaszerkezetek mechanikai alapú méretezése költséghatékonyan elvégezhetó legyen.

A ciklikus CBR-eljárás hazai talajok stabilizálhatóságának mérésében történô alkalmazhatóságára indított kísérlet-sorozat elsố eredményeit mutatja be a jelen tanulmány.

\section{Irodalmi áttekintés}

A hazai közúti pályaszerkezet méretezési gyakorlat a típus-pályaszerkezetek rendszerére épül, az erdészeti úttervezésben pedig a CBR-alapú módszer terjedt el. A talaj teherbírását a CBR-értékkel veszik figyelembe. Ez az érték egy viszonyszám, amely megmutatja, hogy egy etalonnak tekintett zúzottkố pályaszerkezeti réteg teherbírásához képest a vizsgált anyag mekkora teherbírású. A teherbírást azzal az eróvel jellemzik, ami ahhoz szükséges, hogy egy $50 \mathrm{~mm}$ átmérójú fém hengert 1,27 $\mathrm{mm} / \mathrm{s}$ sebességgel $2,5 \mathrm{~mm}$ mélységben az elő́rás szerint elkészített talajmintába nyomjunk. A mért eróboól az (1) képlet segítségével számítható a CBR-érték. A vizsgálat elvégzéséhez egy terheló keretre, valamint egy erő-, illetve egy elmozdulásmérôre van szükség. Ezek az eszközök a legtöbb talaj-, illetve útlaborban rendelkezésre állnak, és használatuk rutinszerúen történik. 


$$
C B R \%=100-\frac{F_{2,5}}{13,2}
$$

ahol: $F_{2,5}=$ a 2,5 $\mathrm{mm}$ benyomódáshoz szükséges erô $(\mathrm{kN})$.

2016-ban Magyarországon is kidolgozásra került egy alternatív pályaszerkezet méretezési eljárás (Primusz és Tóth, 2018), amely lehetóvé teszi a mechanikai alapú méretezést. Ehhez bemenó paraméterként a pályaszerkezeti réteg anyagának rugalmassági modulusára van szükség. A dinamikus terhelés mellett figyelembe vehetố rugalmassági modulusra $(E)$ a reziliens modulus $\left(M_{r}\right)$ ad jó becslést. A reziliens modulus a deviátor feszültség és a rugalmas alakváltozás arányaként írható fel, amelynek mértéke függ az oldalirányú nyomástól (Back és Szendefy, 2017). A feszültségállapot mellett, a reziliens modulus értékét a földmú víztartalma és hómérséklet eloszlása is jelentősen befolyásolja, melynek számítására már több módszert is kidolgoztak (Pap M, Mahler A és Tóth Cs, 2017).

A reziliens modulus közvetlen meghatározása dinamikus triaxiális vizsgálóberendezéssel történik. A vizsgálat alatt a mintát állandó cellanyomás mellett ciklikus, gyors $(0,1 \mathrm{mp})$, tengelyirányú terhelésnek teszik ki. Ezzel a pályaszerkezet valós igénybevételét lehet modellezni, ahol a gyorsan mozgó jármúvek hasonlóan rövid ideig terhelik a szerkezet egy adott pontját. A vizsgálathoz használt berendezés költséges, használata összetettebb, mint a CBR-vizsgáló berendezésé, ezért alkalmazása annál kevésbé elterjedt.

A mechanikai alapú méretezéshez szükséges reziliens modulus meghatározására kézenfekvô eljárásnak túnt összefüggést keresni a könnyen meghatározható $C B R$ és a reziliens modulus $\left(M_{r}\right)$ értéke között. A kutatók több modellt is kidolgoztak, amelyek segítségével a CBR-érték átszámítható reziliens modulus értékre. Háromféle modell alkalmazása terjedt el: Iineáris (Heukelom és Klomp, 1962;
Ohio DOT, 2008), hatványos (Green és Hall, 1975; Hopkins, 1994; Paterson és Maree, 1978; Powell et al., 1984; Uzan, 1985; Webb és Campbell, 1986) és polinomiális (Kenya Road Design Manual, 1987; Mukabi, 2016). Az átszámítási képleteket az 1. táblázat mutatja be. Fontos kiemelni, hogy a modellek alkalmazását meghatározott talajokra és CBR tartományokra javasolják, illetve hogy a használatukkal nyert reziliens modulus értékek esetenként nagy szórást mutatnak (Back és Szendefy, 2017).

A klasszikus CBR-vizsgálat egy terhelése alatt a vizsgált minta plasztikus és rugalmas alakváltozást is szenved, ezért Opiyo (1995) feltételezte, hogy ebból az egy értékból nem lehet tisztán a rugalmas tulajdonságokra következtetni, vagyis a CBR-érték nem számítható át megbízhatóan rugalmassági modulussá. Ezért 1995-ben kidolgozta a ciklikus CBR-vizsgálat módszerét azzal a céllal, hogy a talajok, illetve szemcsés útépítési anyagok rugalmassági modulusát egyszerú, már meglévó eszközökkel lehessen meghatározni. A vizsgálatot más kutatók sikerrel alkalmazták kötött talajokra és stabilizált talajokra is (Sas et al., 2012; Sas és Głuchowski, 2013). A CBR-vizsgálat elsó lépcsóje (2,5 $\mathrm{mm}$ benyomódás, 1,25 mm/perc sebességgel) után további teherismétléseket javasolt. Az ismétléseket az elsô lépcsóben elért maximális terheléssel kell elvégezni. Az ismételt terhelések hatására az anyag egyre kisebb maradó alakváltozást szenved. A teherismétlési ciklusokat elméletileg addig kellene folytatni, amíg a minta már csak rugalmas alakváltozást mutat. A gyakorlatban megfelelő, ha az utolsó 5 ciklus együttes, maradó alakváltozása kisebb, mint a teljes maradó alakváltozás 2\%-a. Ez az állapot jellemzóen 50-100 teherismétlés után alakul ki (Araya, 2011; Molenaar, 2011). A rugalmas alakváltozást jól jellemzi az utolsó terhelési ciklusban mért alakváltozás, valamint az ezt kiváltó erố (1. ábra).

\section{1. táblázat. Különféle átszámítási képletek CBR-ról rezilens modulusra}

\begin{tabular}{|c|c|c|c|}
\hline A modell típusa & A modell kidolgozója & Átszámító képlet & $\begin{array}{l}\text { Ajánlott CBR } \\
\text { tartomány }\end{array}$ \\
\hline \multirow[t]{2}{*}{ Lineáris } & (Heukelom és Klomp, 1962) & $M_{r}=10,340 \cdot C B R$ & $10-20$ \\
\hline & (Ohio DOT, 2008) & $M_{r}=8,274 \cdot C B R$ & \\
\hline \multirow[t]{6}{*}{ Hatványos } & (Green and Hall, 1975) & $M_{r}=37,268 \cdot C B R^{0,711}$ & $2-200$ \\
\hline & (Paterson és Maree, 1978) & $M_{r}=20,670 \cdot C B R^{0,65}$ & \\
\hline & (Powell et al., 1984) & $M_{r}=17,616 \cdot C B R^{0,64}$ & $2-12$ \\
\hline & $($ Uzan, 1985) & $M_{r}=91,226+0,017 \cdot C B R^{2}$ & \\
\hline & (Webb és Campbell, 1986) & $M_{r}=21,470 \cdot C B R^{0,478}$ & \\
\hline & (Hopkins, 1994) & $M_{r}=17,914 \cdot C B R^{0,874}$ & \\
\hline \multirow[t]{2}{*}{ Polinomiális } & (Kenya Road Design Manual, 1987) & $M_{r}=0,0162 \cdot C B R^{3}-0,5454 \cdot C B R^{2}+10,062 \cdot C B R$ & \\
\hline & (Mukabi, 2016) & $M_{r}=0,0022 \cdot C B R^{3}-0,1273 \cdot C B R^{2}+6,4261 \cdot C B R$ & $<170$ \\
\hline
\end{tabular}




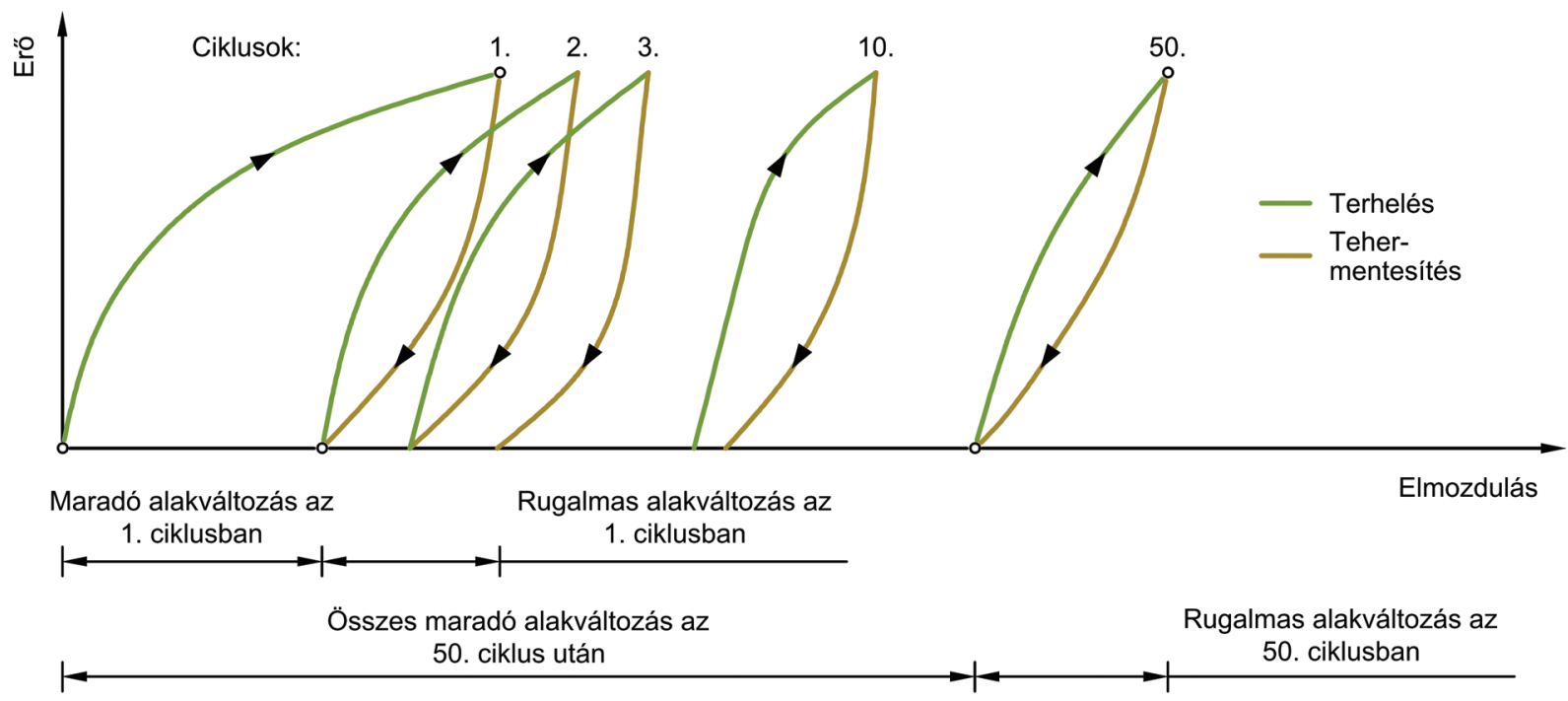

1. ábra. A ciklikus CBR-vizsgálat sematikus eró-elmozdulás grafikonja

Ez a két változó, valamint néhány segédparaméter ismeretében több egyenletet is kidolgoztak a kutatók a reziliens modulus meghatározására. Opiyo (1995) eredeti összefüggését a (2) egyenlet mutatja be, míg Molenaar (2011) a (3) egyenletet állította fel.

$$
E=\frac{\sigma d}{u d}\left[\frac{d(L-H)}{D}\right]
$$

ahol: $E$ : modulus (reziliens) (MPa)

$\sigma$ : átlagos nyomófeszültség ( $\mathrm{MPa}$ )

$d$ : a terhelô felület átméróje $(\mathrm{mm})$

$u$ : rugalmas alakváltozás $(\mathrm{mm})$

$L$ : a minta magassága $(\mathrm{mm})$

$H$ : a kúpos rész magassága $(\mathrm{mm})$

$D$ : a minta átméróje $(\mathrm{mm})$

A fenti összefüggésben használt változók pontos értelmezését a 2 . ábra segíti.

$$
E_{\text {equ }}=\frac{1,513\left(1-v^{1,104}\right) \sigma_{p} \cdot a}{u^{1,012}}
$$

ahol: $E_{\text {equ }}$ : ekvivalens modulus (MPa)

$v$ : Poisson szám (-)

$\sigma_{\mathrm{p}}$ : átlagos nyomófeszültség (MPa)

$u$ : Rugalmas alakváltozás $(\mathrm{mm})$

a : A terheló felület sugara $(\mathrm{mm})$

\section{Anyag és Módszer}

\section{Mintaterület}

A teherbírás-vizsgálatokat egy átfogó kutatás keretében végeztük, amihez az EGERERDÖ Zrt. biztosított helyszínt. A cég Parádfürdói Erdészetének terü-

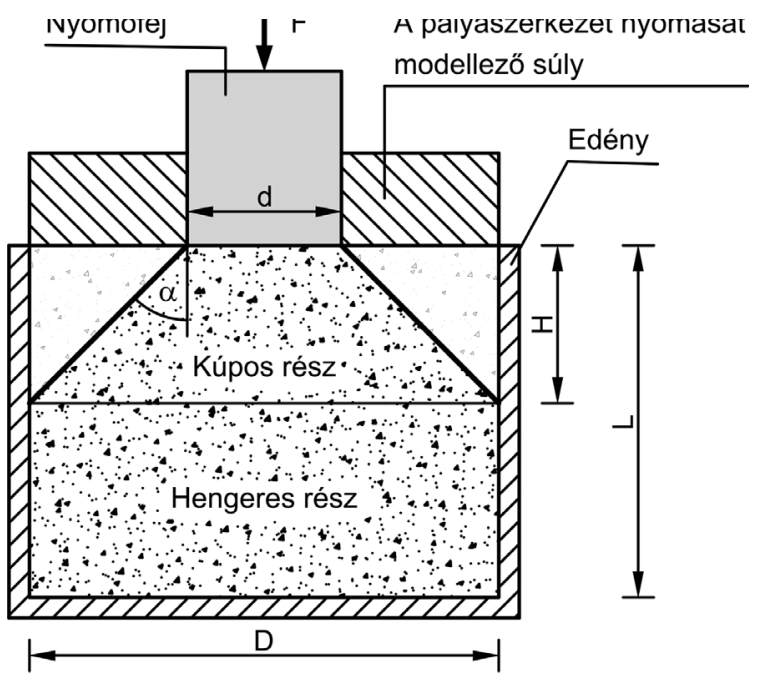

2. ábra. A ciklikus CBR vizsgálat feldolgozásánál használt méretek értelmezése (Opiyo, 1995)

(http://utugyilapok.hu/wp-content/uploads/2015/11/ Analitikus-TU.pdf)

letén jellemzóen kötött talajok találhatók, amelyek az útépítés szempontjából kedvezótlen körülményt jelentenek. A talajok stabilizálhatóságát egy konkrét, problémás út - "Glóbuszi" erdészeti feltáróút - mintáján demonstráltuk. Az út közvetlen közeléból, a humuszos réteg alatti réteg felsó $50 \mathrm{~cm}$ vastag sávjából mintegy $300 \mathrm{~kg}$ talajmintát vettünk. A mintavétel pontos helye (3. ábra) $A Z$ EOV koordinátákkal megadva: $Y=284495,4$; $X=720066,5$.

\section{A vizsgált talaj}

A talajon elvégeztük a talajazonosításhoz szükséges talajmechanikai vizsgálatokat. A talaj folyási 


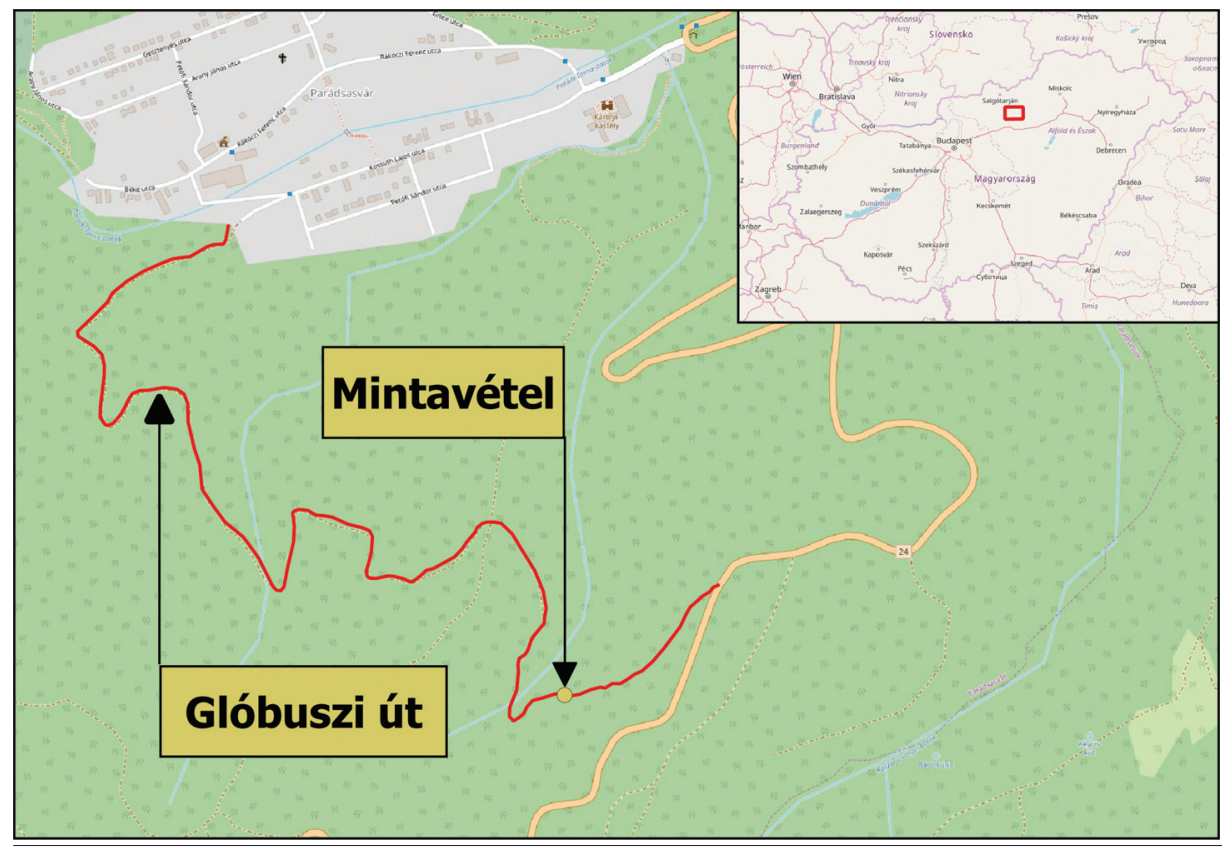

3. ábra. A talajmintavétel helye

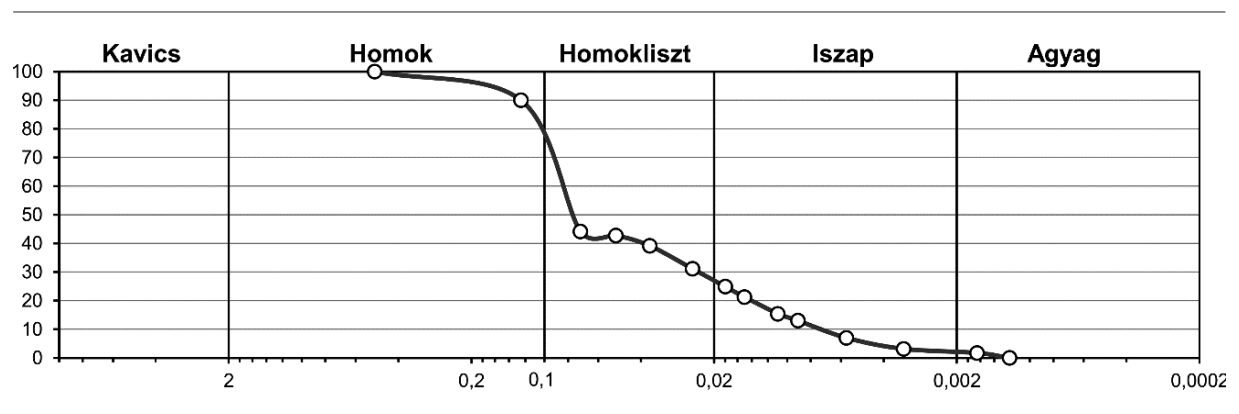

\section{4. ábra. A vizsgált talaj szemeloszlási görbéje}

határa $\left(W_{L}\right) 40,71 \%$, a sodrási határa $\left(W_{P}\right)$ 22,85\%, a plasztikus indexe (IP) 17,86\%-ra adódott. A talaj szemeloszlási görbéjét a 4 . ábra mutatja be. A plasztikus index alapján a vizsgált talajt sovány agyagként azonosítottuk, míg a szemeloszlási gör- be szerint az iszapos homokliszt kategóriába került. A talaj 15,8\% víztartalom mellett tömöríthetô legjobban, maximális halomsúrúsége 1,81 g/ $\mathrm{cm}^{3}$. Az irodalmi adatok alapján a talaj várható reziliens modulus értéke 60-100 MPa érték körül alakul (Drumm et al., 1990; Bandara és Rowe, 2003).

\section{Próbatestek készítése}

A vizsgálathoz a talajmintát levegón szárítással és darálással készítettük eló. Az elókészített talajból 18 féle keveréket készítettünk a 2. táblázat szerinti kötóanyag és víz adagolásával. A talaj szemcseösszetétele alapján kötóanyagként mész, illetve mész-cement keverék jöhetett szóba. Az elózetes, három nap pihentetés után végzett vizsgálatok szerint a mész-cement keverékkel kezelt talajok teherbírása 15-20\%-kal magasabb, ezért ezzel a kötóanyaggal készítettük a próbatesteket. A vizsgálathoz szükséges, $70 \%$ meszet és 30\% cementet tartalmazó kötôanyagot a Carmeuse Hungária Kft. biztosította. A talajkeverékekból szétnyitható CBR edényekben (átmérố $=150 \mathrm{~mm}$, magasság $=114$ $\mathrm{mm}$ ) edényekben mintákat készítettünk. A keveréket öt rétegben, rétegenként 25 ütéssel Proctor-féle

\section{2. táblázat. Kísérleti talaj-kötóanyag keverékek}

\begin{tabular}{|c|c|c|c|c|c|c|c|}
\hline $\begin{array}{c}\text { Minta } \\
\text { száma } \\
\text { \# }\end{array}$ & Kötőanyag & $\begin{array}{c}\text { Kötőanyag- } \\
\text { adagolás } \\
(\mathrm{m} / \mathrm{m} \%)\end{array}$ & $\begin{array}{c}\text { Mért víztarta- } \\
\text { lom } \\
(\mathrm{m} / \mathrm{m} \%)\end{array}$ & $\begin{array}{c}\text { Minta } \\
\text { száma } \\
\#\end{array}$ & Kötőanyag & $\begin{array}{c}\text { Kötőanyag- } \\
\text { adagolás } \\
(\mathrm{m} / \mathrm{m} \%)\end{array}$ & $\begin{array}{c}\text { Mért víztarta- } \\
\text { lom } \\
(\mathrm{m} / \mathrm{m} \%)\end{array}$ \\
\hline MC1 & \multirow{9}{*}{$\begin{array}{l}\text { 70\% mész, } \\
30 \% \text { cement }\end{array}$} & 3 & 10,0 & MC10 & \multirow{9}{*}{$\begin{array}{l}\text { 70\% mész, } \\
30 \% \text { cement }\end{array}$} & 5 & 16,3 \\
\hline MC2 & & 3 & 12,8 & MC11 & & 5 & 18,8 \\
\hline MC3 & & 3 & 15,3 & MC12 & & 5 & 21,4 \\
\hline MC4 & & 3 & 16,4 & MC13 & & 7 & 7,9 \\
\hline MC5 & & 3 & 17,8 & MC14 & & 7 & 10,3 \\
\hline MC6 & & 3 & 20,7 & MC15 & & 7 & 12,5 \\
\hline MC7 & & 5 & 8,9 & MC16 & & 7 & 15,7 \\
\hline MC8 & & 5 & 12,0 & MC17 & & 7 & 20,1 \\
\hline MC9 & & 5 & 14,0 & MC18 & & 7 & 22,7 \\
\hline
\end{tabular}


tömörítógépben tömörítettük be az edényekbe. Az edényból kivett mintákat párazáró csomagolásban 28 napig állni hagytuk.

\section{Ciklikus CBR vizsgálat}

A pihentetés után a CBR mintákat visszatettük az edénybe, majd Multiensayo univerzális terheló berendezés segítségével egy 1,25 mm/perc sebességgel mozgó, $50 \mathrm{~mm}$ átmérójú acél hengerrel terheltük a készítéskori felsô síkot, 2,50mm mélységú behatolásig. Tehermentesítés után a benyomáshoz szükséges maximális eróvel 50 teherismétlést alkalmaztunk. A vizsgálat alatt rögzítettük a terheló fej elmozdulását és az elmozduláshoz szükséges erót.

Az elsố ciklusban mért maximális erô alapján az (1) képlet segítségével számítottuk ki a minták CBR\% értékét. Az utolsó ciklusban mért alakváltozás és a terhelő erô függvényében a (2) képlettel az Opiyo féle, míg a (3) képlettel a Molenaar-féle ekvivalens modulust számítottuk.

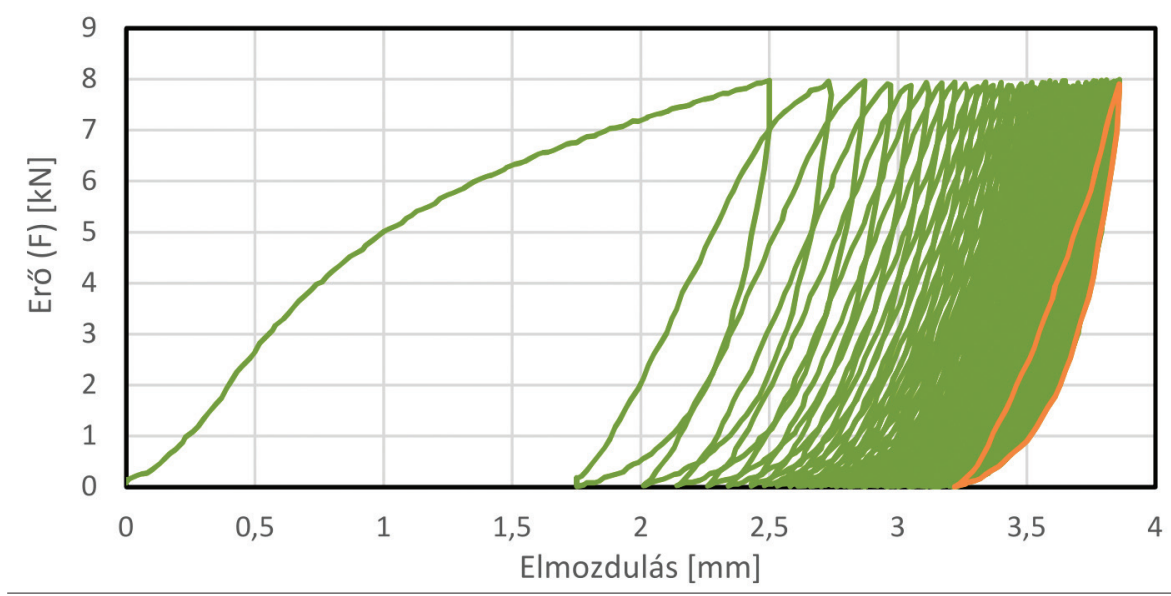

5. ábra. Az MC3 minta ciklikus CBR vizsgálatának eró-elmozdulás grafikonja

\section{CBR átszámítása $M_{r}$-értékre}

A szakirodalom több olyan képletet is bemutat, amelyekkel a CBR érték a szerzók szerint átszámítható reziliens modulus értékké. A kísérleti eredményeken elvégeztük ezeket az átszámításokat annak érdekében, hogy össze lehessen vetni a rugalmassági paramétereket is figyelembe vevó képletek eredményeivel. Az 1. táblázatban bemutatott tíz féle képlettel számítottuk az $M_{r}$ várható értékét.

\section{Eredmények}

A ciklikus terhelés hatására a szakirodalomnak megfelelő erô-elmozdulás grafikon rajzolódott ki (5. ábra) a minták vizsgálatakor. A példán látható, hogy a vizsgált anyag mintegy $3 \mathrm{~mm}$ maradó, és 0,5 $\mathrm{mm}$ rugalmas alakváltozást szenvedett az 50. ciklus végén.

A mért CBR, illetve a kétféle összefüggéssel számított $M_{r^{-}}$értékeket a 3. táblázat tartalmazza. A min-

ták CBR-értékei 13 és 80 CBR\% között változtak, az átlagos CBR-érték 53,9 CBR\% (szórás: 16,3\%) volt. Az Opiyo szerint számított rezilens modulusok átlaga 44,2 MPa (szórás: 13,1 MPa), a Molenaar-féle számítás szerintiek átlaga 157,6 MPara (szórás: 46,9 MPa) adódott.

A kísérletben feltételeztük, hogy a stabilizáció teherbírása függ a kötóanyag típusától, a kötôanyag adagolástól, illetve a talaj víztartalmától. Az erre vonatkozó eredményeket a 6. ábra és a 7. ábra

3. táblázat. A talajkeverékek számított CBR értékei, valamint az Opiyo, illetve Molenaar képletével számított egyenértékú modulusai

\begin{tabular}{|c|c|c|c|c|c|c|c|}
\hline $\begin{array}{c}\text { Minta } \\
\#\end{array}$ & $\begin{array}{c}\text { CBR } \\
(\%)\end{array}$ & $\begin{array}{c}\text { Mr_Opi } \\
\text { (MPa) }\end{array}$ & $\begin{array}{c}\text { Mr_Mole } \\
(\mathrm{MPa})\end{array}$ & $\begin{array}{c}\text { Minta } \\
\#\end{array}$ & $\begin{array}{c}\text { CBR } \\
(\%)\end{array}$ & $\begin{array}{c}\text { Mr_Opi } \\
\text { (MPa) }\end{array}$ & $\begin{array}{c}\text { Mr_Mole } \\
(\mathrm{MPa})\end{array}$ \\
\hline MC1 & 36,0 & 33,0 & 117,5 & MC10 & 71,3 & 54,8 & 196,6 \\
\hline MC2 & 59,9 & 42,9 & 152,3 & MC11 & 65,4 & 53,5 & 190,3 \\
\hline MC3 & 58,1 & 34,6 & 122,4 & MC12 & 29,8 & 27,3 & 97,2 \\
\hline MC4 & 58,8 & 44,6 & 160,0 & MC13 & 39,3 & 33,3 & 118,6 \\
\hline MC5 & 54,3 & 42,9 & 152,4 & MC14 & 63,3 & 56,9 & 202,4 \\
\hline MC6 & 49,8 & 40,7 & 144,8 & MC15 & 72,0 & 64,7 & 230,3 \\
\hline MC7 & 41,7 & 33,5 & 119,2 & MC16 & 80,3 & 63,5 & 239,3 \\
\hline MC8 & 56,3 & 53,7 & 191,4 & MC17 & 55,8 & 50,1 & 178,4 \\
\hline MC9 & 66,1 & 48,8 & 173,4 & MC18 & 12,6 & 14,1 & 50,4 \\
\hline
\end{tabular}




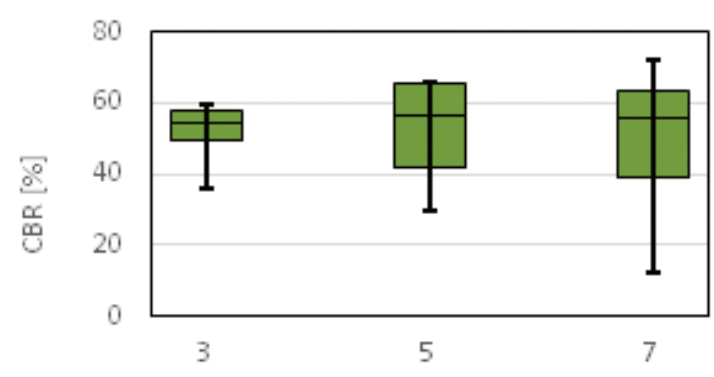

Kötốanyag adagolás [\%]

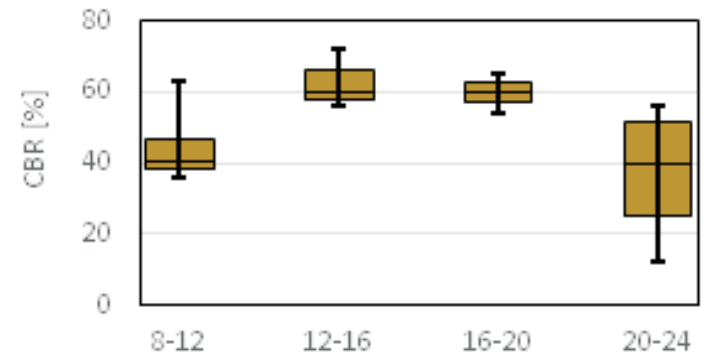

Viztartalom [\%]

\section{6. ábra. A keverékek CBR-értéke a kötőanyag-adagolás függvényében}
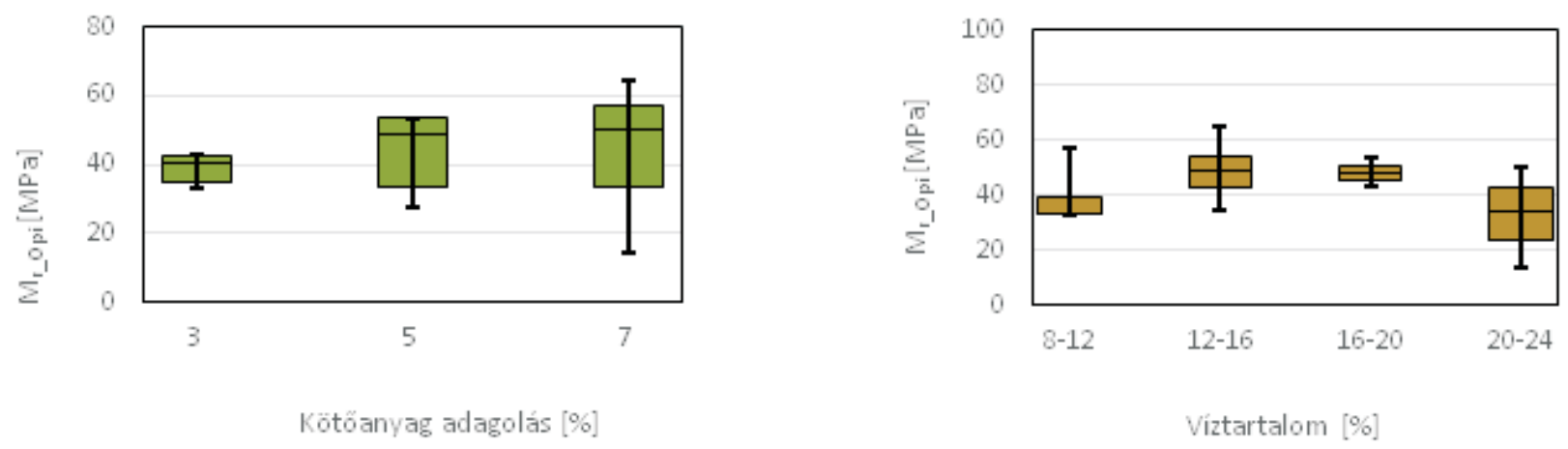

\section{7. ábra. A keverékek $M_{r}$-értéke a víztartalom függvényében}

mutatja be. A box-plot ábrák alapján az látszik, hogy a kötőanyag adagolás nagysága csak kis mértékben befolyásolta a minták átlagos CBR-, illetve $M_{r}$-értékeit. Ezt erósítik meg a 4. táblázat korrelációs adatai is. Ezzel szemben úgy túnik, hogy a talaj víztartalma nagyobb hatással van a teherbírásra. A 6. ábra alapján a mintákra megadható egy, a CBR, illetve az $M_{\mathrm{r}}$-érték szempontjából optimálisnak tekinthetô víztartalom.

A számított $M_{r}$-értékeket megvizsgálva szembetúnó, hogy a két adatsor között szoros összefüggés van (4. táblázat), ám a Molenaar-féle képlet háromszor magasabb értéket ad, mint az eredeti, Opiyoféle. A két összefüggést különbözó talajra és

\section{4. táblázat. Korreláció a vizsgált változók között}

\begin{tabular}{|c|c|c|c|c|c|c|c|c|}
\hline$W_{\text {terv }}$ & $W_{\text {mért }}$ & Alakv. & $F_{2,5}$ & F/alak & $\mathrm{CBR}_{2,5}$ & Mr_Opi & $M_{r_{2} \mathrm{Mol}}$ & $M C$ \\
\hline \multirow[t]{9}{*}{0,00} & $-0,05$ & $-0,58$ & $-0,08$ & 0,16 & $-0,08$ & 0,16 & 0,16 & B \\
\hline & 0,65 & 0,12 & 0,11 & 0,03 & 0,11 & 0,03 & 0,03 & $W_{\text {terv }}$ \\
\hline & & $-0,16$ & $-0,27$ & $-0,27$ & $-0,27$ & $-0,27$ & $-0,27$ & $W_{\text {mért }}$ \\
\hline & & & 0,47 & 0,09 & 0,47 & 0,09 & 0,09 & Alakv. \\
\hline & & & & 0,92 & 1,00 & 0,92 & 0,91 & $F_{2,5}$ \\
\hline & & & & & 0,92 & 1,00 & 1,00 & F/alak \\
\hline & & & & & & 0,92 & 0,91 & $\mathrm{CBR}_{2,5}$ \\
\hline & & & & & & & 1,00 & $E_{\text {Opi }}$ \\
\hline & & & & & & & & $\mathrm{E}_{\mathrm{Mol}}$ \\
\hline & 0,95 & & 0,9 & & 0,8 & & 0,6 & \\
\hline
\end{tabular}

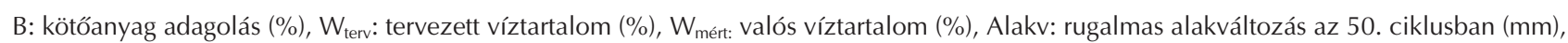
$\mathrm{F}_{2,5}$ : a 2,5 mm behatoláshoz szükséges eró ( $\left.\mathrm{kN}\right)$, F/alak: az F2,5 és az alakváltozás hányadosa (-), CBR 2,5: a minta mért CBR értéke (\%), Mr_Opi: Az Opiyo-féle képlettel számított reziliens modulus (MPa), Mr_Mole: A Molenaar-féle képlettel számított reziliens modulus (MPa) 
edényméretre dolgozták ki, ami magyarázatot adhat az eltéró eredményre. Az Opiyo-féle képlettel számított modulusok nagyságrendje közelebb áll a vizsgált talaj irodalom alapján becsült modulusához (60-100 MPa).

A kísérletsorozattal célunk volt annak vizsgálata is, hogy a CBR és a reziliens modulus értéke között található-e összefüggés. A 8. ábra a mért CBR-értékeket és a hozzájuk tartozó, Opiyo-féle képlettel számított reziliens modulus értékeket mutatja. A talajminták CBR értékének növekedésével a reziliens modulus értékek is nónek. A pontokra illesztett lineáris, illetve hatvány modell $R_{2}$-értéke
$(0,86$, illetve 0,91$)$ is szoros összefüggést feltételez.

Az 1. táblázatban bemutatott összefüggésekkel kiszámítottuk a mért CBR értékekból becsült reziliens modulus értékeket (9. ábra). Azt tapasztaltuk, hogy a képletek eredményei jelentôs szórást mutatnak, valamint, hogy az Opiyo-féle képlethez képest a CBR-ból számított reziliens modulusok jelentôsen nagyobbak. Ezzel szemben volt olyan átszámító képlet, amelynek eredménye a Molennarféle képlettel számított $M_{r}$-értékekkel jó egyezést mutatott. A $45^{\circ}$-os egyeneshez Uzan, valamint Webb és Campbell (10. és 11. ábra) modellje áll a legközelebb. Az így számított Mr értékek legalább kétszer magasabbak, mint az Opiyo-képlettel számított reziliens modulus értékek, ellenben a Molenaar-féle képletból kapott eredményekkel nagyságrendileg megegyeznek.

\section{Következtetések}

Az eredmények azt mutatják, hogy a vizsgált talajstabilizációk teherbírására nagyobb hatással volt a készítéskori víztartalom, mint a kötóanyag adagolás. Ezen felül megadható volt az optimális víztartalom, ahol a CBR, illetve az Mr értéke a legmaga-

8. ábra. Összefüggés a CBR és a számított Mr értékek között kötóanyag szerinti bontásban

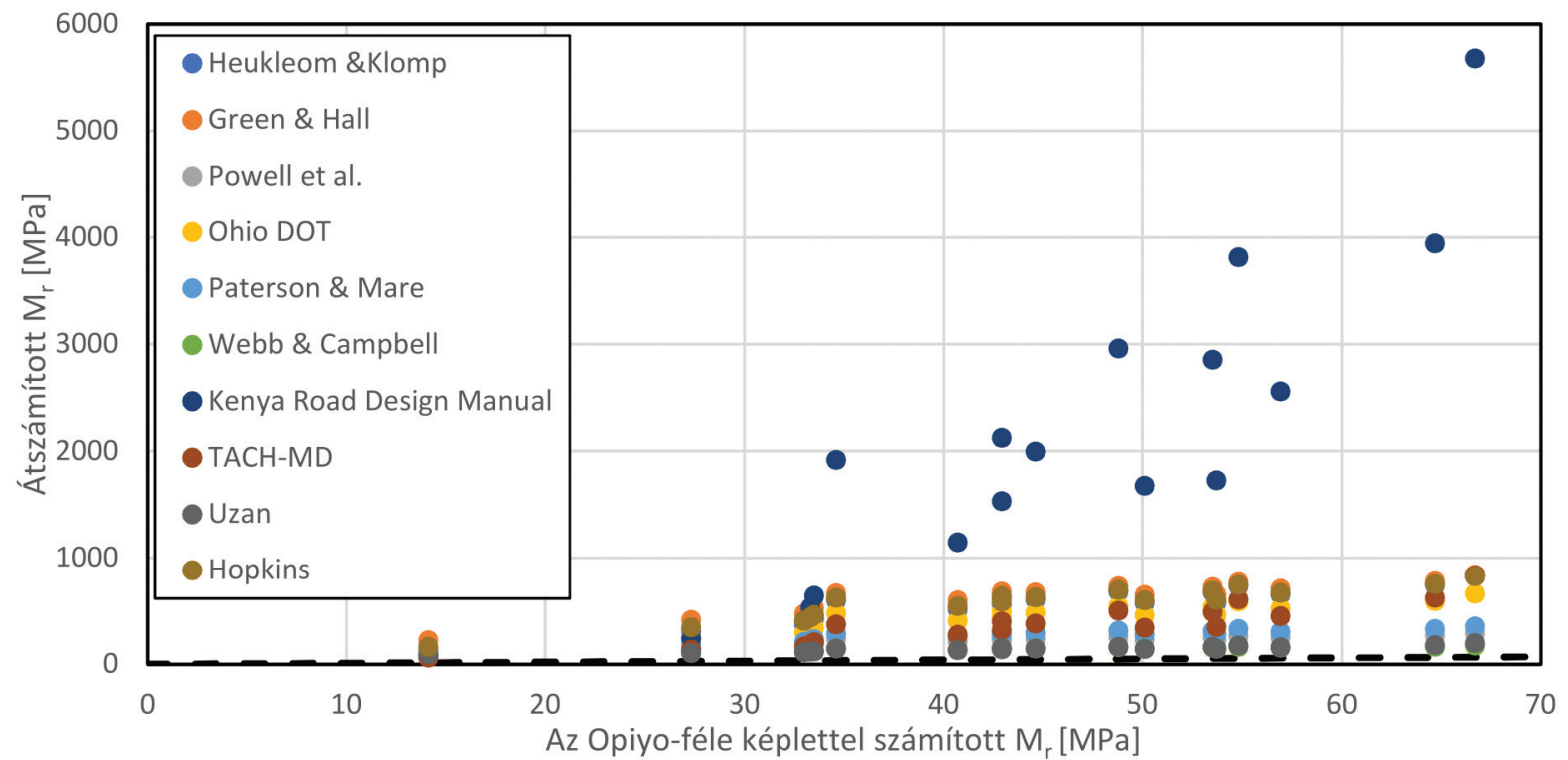

9. ábra. A különbözó CBR átszámítási képletekkel kapott $M_{r}$-értékek összehasonlítása az Opiyo-féle képlettel számított értékekkel 


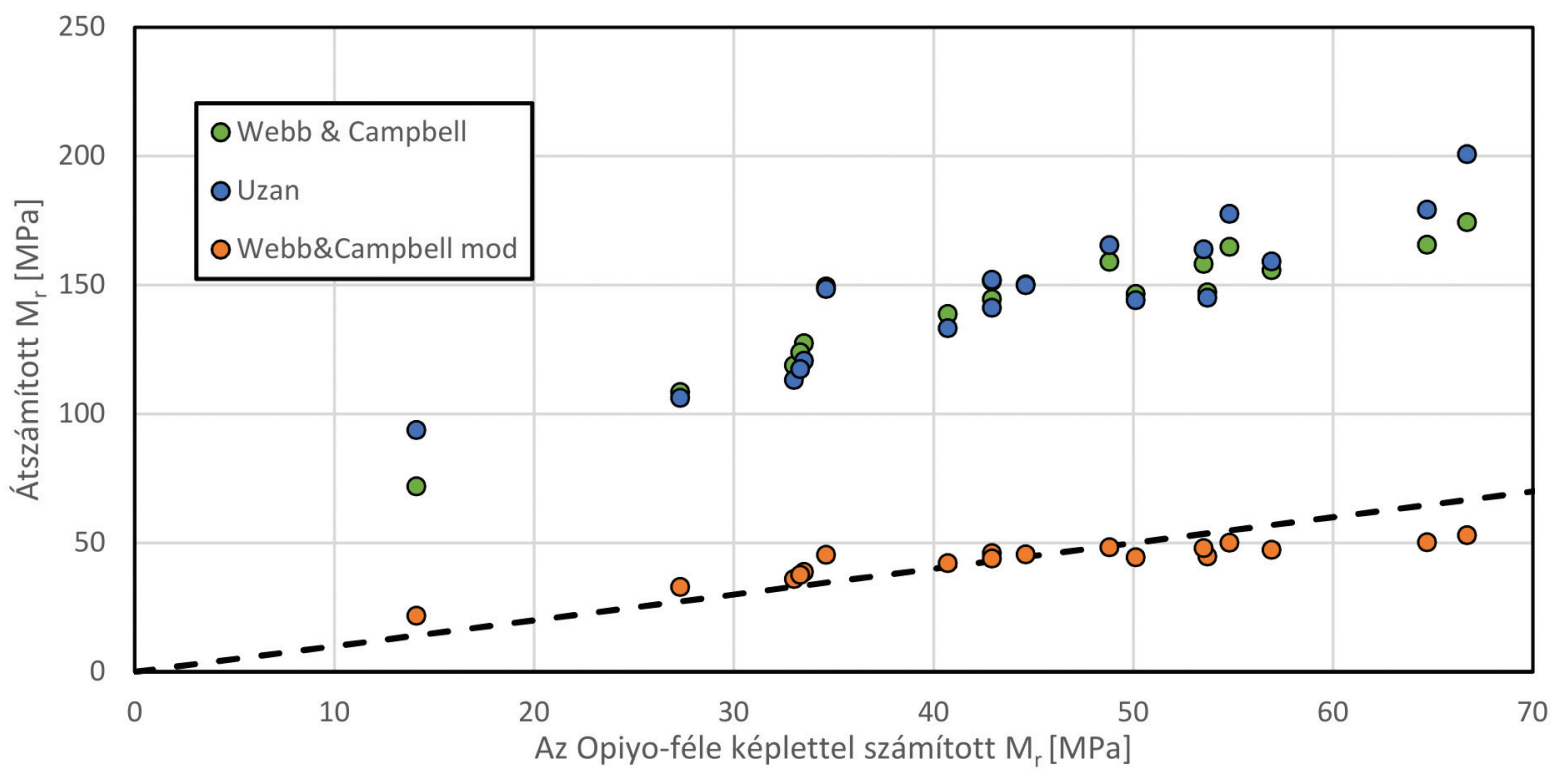

10. ábra. A Webb és Campbell (1986), valamint az Uzan (1985) által javasolt képlettel számított $M_{r}$-értékek összehasonlítása az Opiyo-féle képlettel számított értékekkel

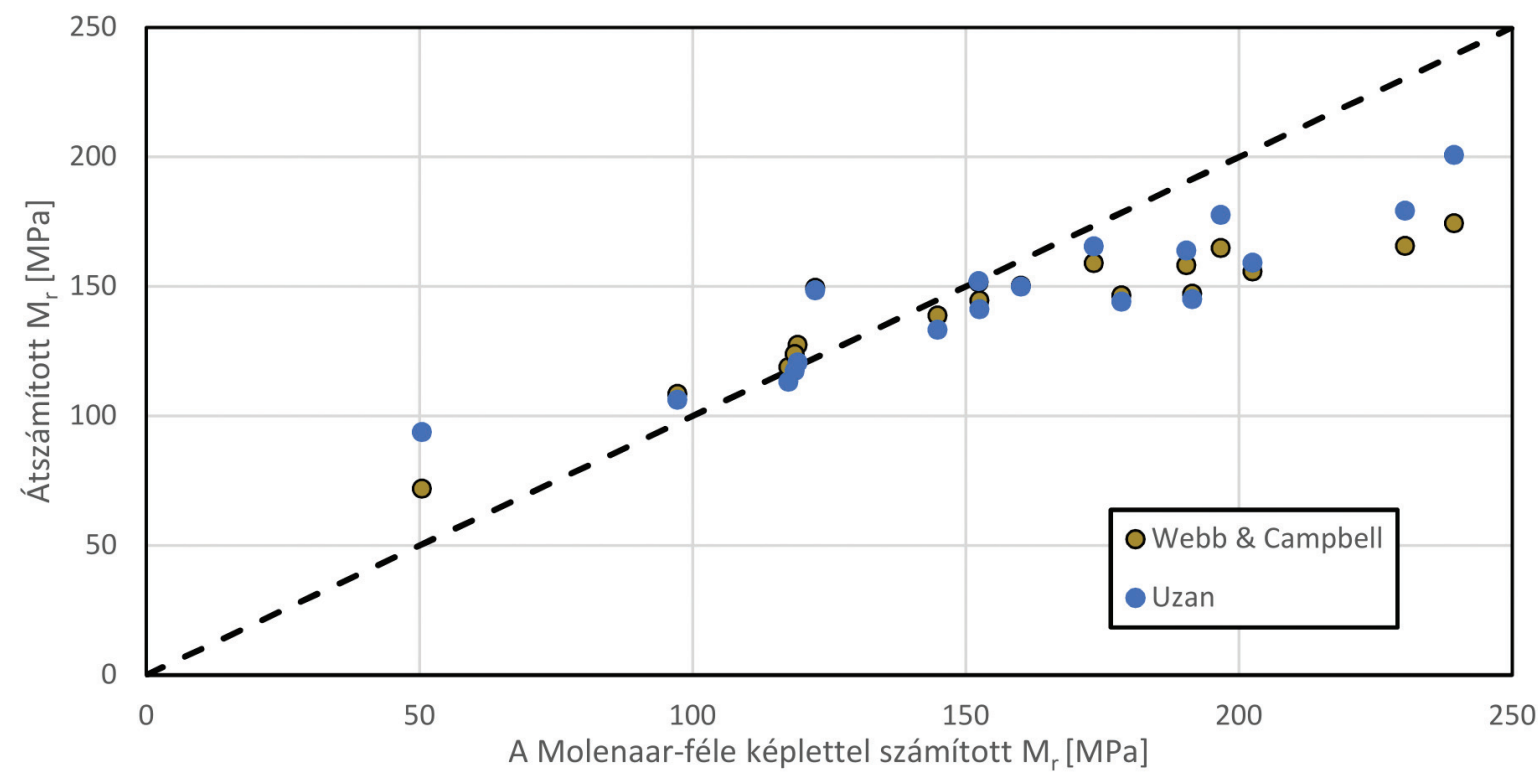

11. ábra. A Webb és Campbell (1986), valamint az Uzan (1985) által javasolt képlettel számított $M_{r}$-értékek összehasonlítása a Molenaar-féle képlettel számított értékekkel

sabb volt. Néhány kísérletból hosszútávú következtetéseket nem szabad levonni, ám az eredmények alapján a stabilizációk készítésénél a talaj víztartalmának optimális értéken tartása a teherbírás szempontjából fontosabb, mint a kötóanyag pontos adagolása.

A ciklikus CBR-vizsgálat ígéretes eljárásnak látszik a stabilizációk rugalmas viselkedésének meghatározására, hiszen a vizsgálat a meglévố CBR-vizsgáló berendezéssel könnyen elvégezhetô, és az eredményekból a reziliens modulus számítható. Opiyo képletével (2) a szakirodalom alapján várt rezilens modulus értékekhez nagyságrendileg hasonló reziliens modulus értékeket számítottunk, míg Molenaar képlete (3) az irodalomban fellelt CBR-Mr átszámító képletek eredményével adott nagyságrendileg azonos eredményt. Back és Szendefy (2017) tiaxiális mérésból származó reziliens modulusokkal összehasonlítva kimutatta, hogy az átszámító képletek jelentôsen túlbecsülhetik a reziliens modulus valós értékét. Emiatt az Opiyo-féle képlet eredményeit a valósághoz közelebb állónak feltételezzük, és a további vizsgálatokig ennek alkalmazását javasoljuk.

A CBR értékból a 9. ábra tanúsága szerint nem számítható nagy biztonsággal a reziliens modulus értéke. A számítások azt mutatták, hogy az egyik legjobban illeszkedó modellt Webb és Campbell 
(1986) dolgozta ki, ami összecseng a Back és Szendefy (2017) által bemutatott eredményekkel. Ezért a reziliens modulus durva becslésére ezt az összefüggést javasoljuk. A mérési adatok alapján a képlet eredményét a 11 . ábra szerint szorozni kellene 0,3-del ahhoz, hogy a jelen kísérletben az Opiyo-féle képlettel meghatározott reziliens modulus értéket kapjuk. Ezt a módosítást azonban nem érdemes alkalmazni, hiszen az Opiyo-féle képletból számított reziliens modulus jóságának ellenőrzésére nem áll rendelkezésre mérési adat.

\section{További kutatás}

A ciklikus CBR-vizsgálat eredményeiból számított reziliens modulus értékek nagyságrendileg a várakozásoknak megfelelóen alakultak, illetve a keverék tulajdonságainak változásával a számított modulus értékek is többé-kevésbé szabályosan változtak. Célszerúnek tartjuk a bemutatott keverékek dinamikus triaxiális vizsgálatát elvégezni annak érdekében, hogy a kétféle számítás közül ki lehessen választani a jobban használhatót, esetleg fel lehessen írni egy, az elôzóeknél pontosabban illeszkedó modellt.

\section{Köszönetnyilvánítás}

A kutatás a "Soproni Egyetem Struktúraváltási Terve" - 32388-2/2017 INTFIN sz. projekt keretében az Emberi Eróforrások Minisztériuma támogatásával valósult meg. A tanulmányban bemutatott vizsgálatokhoz és elemzésekhez a talajt az Egererdó Zrt., a kötóanyagot a Carmeuse Hungária Kft. biztosította.

\section{Felhasznált irodalom}

Araya A, Molenaar AAA, Houben L. A Realistic Method of Characterizing Granular Materials for Low-Cost Road Pavements. Delft University of Technology, Delft, Netherland, 2010; 10.

Araya AA. Characterization of Unbound Granular Materials for Pavements (PhD disszertáció). Delft University of Technology, Delft, Hollandia. 2011.

Back M, Szendefy J. Reziliens modulus mérése és talajstabilizációknál mért értéke. Útügyi Lapok. 2017. http://utugyilapok.hu/cikkek/reziliens-modulus-meresees-talajstabilizacioknal-mert-erteke/

Bandara N, Rowe GM. Design Subgrade Resilient Modulus for Florida Subgrade Soils, in: Durham GN, Marr WA, DeGroff, WL (Eds.), Resilient Modulus Testing for Pavement Components, STP. ASTM International, West Conshohocken, PA, USA, 2003; 274, https://doi.org/10.1520/STP12524S

Drumm EC, Boateng-Poku Y, Johnson Pierce T. Estimation of Subgrade Resilient Modulus from Standard Tests. J. Geotech. Eng. 1990; 116:774-789.

https://doi.org/10.1061/(asce)0733-9410(1990)116:5(774
Green JL, Hall JW. Nondestructive vibratory testing of airport pavements. Waterways Experiment Station, Vicksburg, Miss. 1975.

Heukelom W, Klomp AJG. Dynamic testing as a means of controlling pavement during and after construction. Presented at the 1 st International Conference on the Structural Design of Asphalt Pavements, Ann Arbor, Michigan, 1962; pp. 495-510.

Hopkins T. Minimum bearing strength of soil subgrades required to construct flexible pavements, in: Proceedings of the 4th International Conference, Bearing Capacity of Roads and Airfields. Minnesota Department of Transportation, Minneapolis, MN, USA, 1994; pp. 605-617.

Kenya Road Design Manual, Road design manual, Part III: Materials and pavements design for new roads. Ministry of Transportation and Communications, Nairobi, Kenya. 1987.

Molenaar AAA. Characterization of unbound base materilas for roads using a new developed repeated load CBR test. Presented at the 8th International Conference on Managing Pavement Assets, Santiago de Chile, Chile. 2011.

Mukabi JN. Review of DCP Based CBR UCS and Resilient Modulus Models for Applications in Highway and Airport Pavement Design. Acad. E-Publ. Pre-Print. 2016.

Ohio DOT. Pavement Design Manual. The Ohio Department of Transportation, Office of Pavement Engineering, Colombus, Ohio, USA. 2008.

Opiyo TO. A Mechanistic Approach to Laterite-based Pavements (M.Sc thesis). International Institute for Infrastructural, Hydraulic and Environmental Engineering, Delft. 1995.

Pap M, Mahler A, Tóth Cs. Klimatikus viszonyok hatása a reziliens modulusra I.: Környezeti hatások és talajjellemzốk meghatározása, Útügyi Lapok 2017; 5(10):49-57.

Pap M, Mahler A, Tóth Cs. Klimatikus viszonyok hatása a reziliens modulusra II.: Reziliens modulus meghatározása, Útügyi Lapok 2017; 5(10)58-63.

Paterson WDL, Maree JH. An interim mechanistic procedure for the structural design pavements. National Institute for Transport and Road Research, Pretoria, South Africa, 1978.

Primusz P, Tóth Cs. Aszfaltburkolatú útpályaszerkezetek egyszerúsített analitikus méretezése. Közlekedéstudományi szemle, 2018; 68(5):17-33. ISSN 0023-4362, https://doi.org/10.24228/KTSZ.2018.5.2

Powell WD, Potter JF, Mayhew HC, Nunn ME. The structural design of bituminous roads (No. LR1132). TRRL, Crowthorne, Berkshire, UK. 1984.

Sas W, Głuchowski A. Rutting prediction for stabilized soils based on the cyclic CBR test. Roads Bridg. Drogi Mosty 2013; 411-423, https://doi.org/10.7409/rabdim.013.026

Sas W, Głuchowski A, Szymański A. Determination of the Resilient Modulus Mr for the Lime Stabilized Clay Obtained from the Repeated Loading CBR Tests. Ann. Wars. Univ. Life Sci. - SGGW Land Reclam. 2012; 44. https://doi.org/10.2478/v10060-011-0070-0

Uzan J. Characterization of granular material. Transp. Res. Rec. $1985 ; 1022: 52-59$.

Webb WM, Campbell BE. Preliminary Investigation into Resilient Modulus Testing for New AASHTO Pavement Design Guide. Office of Materials and Research, Georgia Department of Transportation, Atlanta, GA, USA. 1986. 